\title{
The biotechnological control of pitch in paper pulp manufacturing
}

\section{Ana Gutiérrez, José C. del Río, María Jesús Martínez and Angel T. Martínez}

\begin{abstract}
At present, microbial and enzymatic preparations for the control of triglyceride-containing pitch deposits during the manufacture of mechanical and sulfite paper is commercially available. However, biotechnological products for pitch control in other pulping processes, such as alkaline pulping, are under development. These products include new fungi for the removal of steroids involved in pitch deposit formation in chlorine-free pulps, to be used as a biological pretreatment of wood before pulping. Simultaneously, tailor-made enzymes are being produced using protein-engineering techniques, enabling the specific removal of pitch contaminant compounds from paper pulp.
\end{abstract}

Wood extractives (i.e. those compounds that are extractable from wood with organic solvents) cause production and environmental problems in pulp and paper manufacturing. The lipophilic compounds, which form the so-called wood resin, are the most problematic and they include free fatty acids, resin acids, waxes, fatty alcohols, sterols, sterol esters, glycerides, ketones and other oxidized compounds ${ }^{1-4}$. In addition to these compounds that are soluble in nonpolar solvents, wood extractives include a variable proportion of polar compounds. Table 1 shows the composition of lipophilic extractives from several woody angiosperms (hardwoods) and gymnosperms (softwoods). Moreover, there are differences in resin content and composition between different parts of the tree (including between heartwood and sapwood) and, depending on the age of tree, the growing conditions and other genetic and environmental factors ${ }^{5}$.

During wood pulping and refining of paper pulp (Box 1, Refs 2,6), the lipophilic extractives in the parenchyma cells and softwood resin canals is released, forming colloidal pitch. These colloidal particles can coalesce into larger droplets that deposit in pulp or machinery forming 'pitch deposits', or remain suspended in the process waters. Pitch deposition results in low quality pulp and can cause the shutdown of mill operations ${ }^{7}$. Economic losses associated with pitch problems in kraft mills often amount to $1 \%$ of sales. The main cost components of pitch in pulp mills are the loss of money as a result of contaminated pulp, lost production and the cost of pitch control additives ${ }^{8}$. Pitch present in contaminated pulp is the source of the problems in paper machine operation, including the production of spots and holes in the paper, sheet breaks and technical shutdowns ${ }^{9}$. Moreover, the increasing need for recirculating water in pulp mills is leading to an increase in pitch concentration, which results in higher deposition. In addition, some wood extractives could have a detrimental environmental impact when released into wastewaters. This is especially important in modern environmentally sound pulp manufacturing processes (Box 1). In these processes, chlorine bleaching has been substituted by elemental chlorine-free (ECF) or totally chlorine-free (TCF) bleaching. In the chlorine-free effluents from TCF mills, resin acids, fatty acids and steroids released from wood during pulping have become the primary source of toxicity ${ }^{10,11}$.

Pitch problems originate with the extractives in the different types of wood but also depend on the

Table 1. Composition of lipophilic extractives from pine, spruce, birch, poplar and eucalypt wood $\left(\mathrm{mg} \mathrm{g}^{-1}\right)$

\footnotetext{
Ana Gutiérrez*

José C. del Rio

Instituto de Recursos

Naturales y Agrobiología,

(IRNAS), Consejo Superior

de Investigaciones

Científicas (CSIC),

PO Box 1052, E-41080

Seville, Spain.

*e-mail:

anagu@irnase.csic.es

María Jesús Martínez Angel T. Martínez

Centro de Investigaciones Biológicas (CIB), Consejo

Superior de

Investigaciones Científicas (CSIC), Velázquez 144,

E-28006 Madrid, Spain.
}

\begin{tabular}{|c|c|c|c|c|c|}
\hline & Softwc & ods & & Hardwoods & \\
\hline & Pinus sylvestris & Picea abies & Betula verrucosa & Populus tremula & Eucalyptus globulus \\
\hline Free fatty acids & 1.73 & 0.78 & - & 1.06 & 0.28 \\
\hline Resin acids & 6.65 & 2.85 & 0.06 & 0.17 & 0 \\
\hline Hydrocarbons & 0.74 & 0.19 & 0.40 & 1.14 & 0.17 \\
\hline Waxes or sterol esters & 0.83 & 0.87 & 1.96 & 3.07 & 0.57 \\
\hline Monoglycerides & 0.18 & 0.55 & 2.24 & 1.18 & 0.02 \\
\hline Diglycerides & 0.32 & 0.55 & 1.72 & 0.58 & 0.02 \\
\hline Triglycerides & 8.74 & 1.94 & 8.10 & 10.37 & 0.13 \\
\hline Higher alcohols or sterols & 1.39 & 1.00 & 1.56 & 2.40 & 0.68 \\
\hline Oxidized compounds & 0.43 & 1.36 & 2.94 & 1.53 & 0.22 \\
\hline Lipophilic compounds & 22.9 & 10.4 & 20.3 & 22.7 & 2.60 \\
\hline Total acetone extract & 31.0 & 22.2 & 34.6 & 45.3 & 15.2 \\
\hline
\end{tabular}


Box 1. Paper pulp manufacturing processes: wood pulping and bleaching

Paper pulp manufacturing is the first non-food industrial utilization of plant biomass. This industrial process consists of: (1) pulping the wood to separate fibers by chemical or mechanical means; and

(2) bleaching the pulp by the sequential action of chemical reagents and alkaline extractions. The main differences between the two pulping processes are the yield, up to $99 \%$ for mechanical pulps and $\sim 50 \%$ for chemical pulps, and the quality of the paper that has significantly higher mechanical properties in the case of chemical pulping. Intermediate yields are obtained when a combination of chemical reagents and mechanical treatment is used, such as in semichemical pulping. Lignin, which acts as a cementing agent between wood fibers at the level of middle lamella, can be partially depolymerized to obtain different chemical pulps. Alkaline kraft pulping (sodium hydroxide and sulfide cooking at $155-180^{\circ} \mathrm{C}$ and 7-11 bar) is the dominant process for wood pulping because of the high quality of the pulps obtained after extensive removal of lignin. Together with lignin, which accounts for $20-30 \%$ wood weight, a fraction of polysaccharides is solubilized during chemical pulping, which results in decreased pulp yield. By contrast, no significant modification or removal of wood constituents is produced during mechanical pulping and very high yields are obtained. Mechanical pulps are obtained using two different processes - stone grinding and refiner pulping - characterized because whole logs or wood

above-mentioned pulping and bleaching processes. Therefore, there is considerable variability in pitch problems from mill to mill, as well as in different areas of a mill. Mechanical pulping and subsequent bleaching scarcely affect resin composition.

Therefore, pitch deposits in mechanical pulping show a chemical composition similar to lipophilic extractives from wood used as a raw material (e.g., triglycerides, resin acids and fatty acids in pitch deposits from pine mechanical pulping ${ }^{12}$ ). In kraft pulping, the total amount of extractives in wood might not be as important as the presence of specific compounds surviving cooking conditions. Under these conditions, the glycerol esters are saponified and the fatty and resin acids dissolved. However, the sterol esters and waxes are saponified much more slowly than the glycerol esters. The sterol esters, waxes and free sterols do not form soluble soaps as do free acids, and therefore, have a tendency to deposit. By contrast, the glycerol and sterol esters are not saponified during acidic cooking, such as sulfite pulping.

ECF bleaching of chemical pulps avoids the pitch troubles associated with chlorinated resin components formed by chlorine bleaching ${ }^{13}$. However, some of the extractives that are destroyed by chlorine dioxide represent a source of specific pitch problems chips are ground, respectively. Mechanical refining, an energy consuming process, is also used to complete fiber separation after chemical treatment in semichemical pulps.

Despite the fact that lignin is pale-brown when extracted under mild laboratory conditions, it turns to dark-brown during chemical pulping as a result of oxidation reactions. Therefore, pulp bleaching using a variety of oxidizing or reducing chemicals and alkaline extractions, in different sequences, is necessary in the production of white paper from chemical pulps. By contrast, comparatively mild bleaching treatments, including hydrogen peroxide and dithionite, are applied to mechanical pulps. Elemental chlorine has been traditionally used to bleach chemical pulps but, despite the high efficiency of this strong oxidant, it must be avoided because of the formation of chlorinated lignins and phenols that are discharged in wastewaters. Environmentallysound bleaching sequences involve the substitution of chlorine by chlorine dioxide, in the case of 'elemental chlorine-free' (ECF) bleaching, and the complete elimination of chlorinated reagents (to be substituted for example by hydrogen peroxide, oxygen, ozone or xylanases) in the case of 'totally chlorine-free' (TCF) bleaching. Despite some difficulties in attaining high brightness degrees, TCF sequences are being introduced in the European pulp and paper industry to completely avoid chlorinated compounds in the mill effluents and final products.

in modern TCF bleaching because it is not affected by the hydrogen peroxide. During TCF bleaching of eucalypt kraft pulp (Box 2), sitosterol and sitosterol esters were found to be the main compounds responsible for pitch deposit formation ${ }^{14,16}$. The higher concentration of these compounds in relation to the saponifiable extractives causes pitch problems in the kraft pulping of eucalypt and other hardwoods, such as aspen (Populus tremuloides), used in the pulp and paper industry ${ }^{17}$.

\section{Natural seasoning of pulpwood}

Traditionally, pitch deposits in paper pulp manufacturing processes have been reduced by seasoning (storage in the woodyard) unbarked or barked logs and wood chips. It is well known that storing reduces the resin content of wood and brings about changes in the nature of the resin. During storage, some extractives are lost through oxidative processes and hydrolysis by plant enzymes, as well as by the action of wood colonizing organisms. The reactions of wood resin components during storage have been studied for several pulpwood species including eucalypt ${ }^{18,19}$. Reduction of resin content occurs significantly faster when the wood is stored in the form of chips because both chemical and microbial 
Box 2. The origin of pitch deposits in hardwood pulps

Eucalypt wood is an important raw material for the manufacturing of paper pulp in countries such as Spain, Portugal, Brazil, Australia and South Africa. Highquality kraft pulps are being obtained from Eucalyptus globulus wood. A study on pitch deposit formation during manufacturing of environmentally-sound kraft pulp from E. globulus wood has been carried out as a prerequisite for the development of pitch biocontrol strategies (see Box 4). Some of the conclusions obtained are of interest for manufacturing of kraft pulps from other woods with similar pitch conditions. Pitch deposits were collected from pulp sheets and processing equipment during the manufacture of totally chlorine-free (TCF) and elemental chlorine-free (ECF) bleached pulps. To identify those wood components responsible for pitch deposit formation, lipophilic extractives have been analyzed from E. globulus wood and pulp, before and after TCF and ECF bleaching. The results from gas chromatography-mass spectrometry (GC-MS) analyses showed free sitosterol as the main constituent of pitch deposits during TCF bleaching (Fig. I). The GC-MS profile obtained was similar to those found during analysis of lipophilic extractives from eucalypt wood and both brown and TCF pulp, in which sitosterol in both free and esterified form, was the dominant sterol. Furthermore, they also contained minor amounts of other sterols including campesterol, stigmastanol, fucosterol, cycloartenol, 24-methylenecycloartanol and citrostadienol (Fig. II). Sitosterol was not affected by kraft cooking and hydrogen peroxide bleaching, being at the origin of the pitch deposits, together with a certain amount of sterol esters surviving the alkaline cooking. The situation was different during ECF bleaching because unsaturated sterols (such as sitosterol) are destroyed by the chlorine dioxide, and only the saturated sterols (such as stigmastanol) were found in both deposits
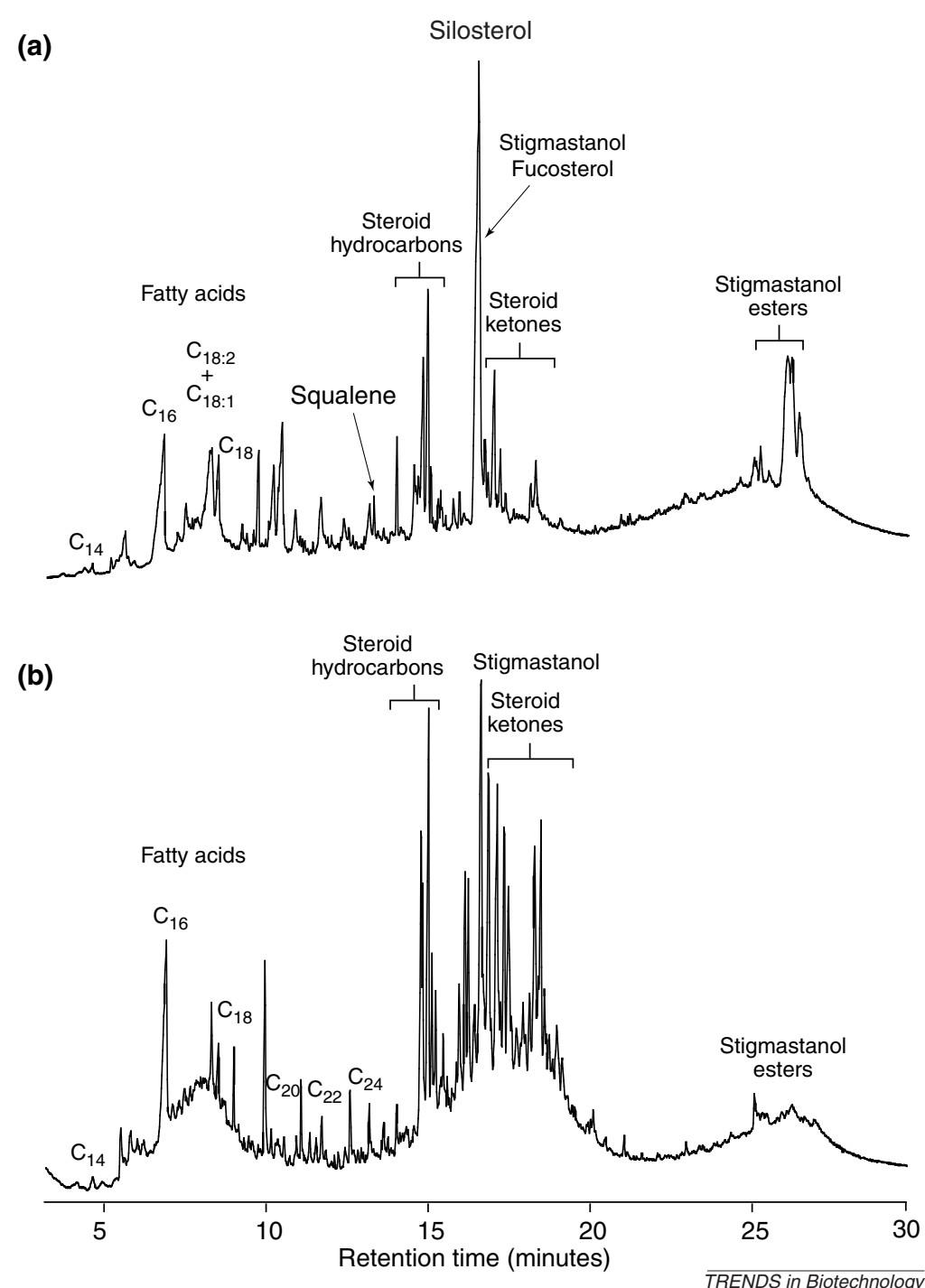

Fig. I. Gas chromatography-mass spectrometry (GC-MS) profiles of lipophilic compounds from pitch deposits following (a) TCF and (b) ECF bleaching ${ }^{14,15}$ (see Fig. Il for compound identification).

and bleached pulp together with several steroid ketones and hydrocarbons.

Unsaturated fatty acids are also destroyed by the chlorine dioxide treatment of pulp. Finally, the non-extractable fraction of the deposits was analyzed using
pyrolysis-GC-MS in the presence of a methylating agent, tetramethylammonium hydroxide, revealing the presence of fatty acid salts (and, in some cases, ligninderived compounds) that were deposited together with the major steroid fraction. transformations proceed faster owing to the increased surface area ${ }^{7}$. Therefore, the storage of wood can reduce pitch problems considerably, but is dependent on the storage conditions. However, it is generally recognized that prolonged wood storage can also result in decreased pulp yield and low pulp quality owing to the action of decay organisms. Hence, the advantages of wood seasoning in minimizing pitch problems must be weighed against the loss of pulp quality that might be sustained through storage.
Pitch biocontrol with Ophiostoma piliferum and other ascomycetous fungi

The biological treatment of wood with fungi to remove extractives before pulping has been suggested and tested in mill trials as an alternative to traditional methods for pitch control ${ }^{20}$. Indeed, a fungal product for pitch degradation has been commercially available since 1991 (Cartapip $\left.{ }^{\circledR}\right)$. The biological pretreatment is a wood seasoning process that is enhanced and accelerated using a selected wood-inhabiting fungus. 
(i)<smiles>CCC(CCC(C)C1CCC2C3CCC4CC(O)CCC4(C)C3CCC12C)C(C)C</smiles>

(iii)

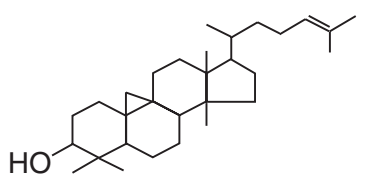

(v)<smiles>CC(C)CCC(C)C1(C)CCC2C3CCC4C(C)C(O)CCC4C3CCC21</smiles>

(vii)

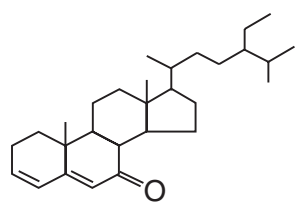

(ix)<smiles>CC(C)CCC(C)C1(C)CCC2C3CCC4CC(O)CCC4C3CCC21</smiles>

(xi)<smiles>CC(C)CCC(C)C1CCC2C1CCC1C3CCC(O)CC3CCC12</smiles>

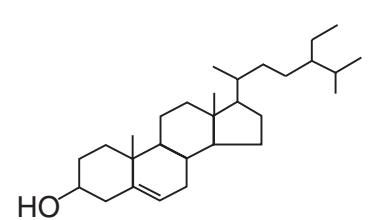

(ii)

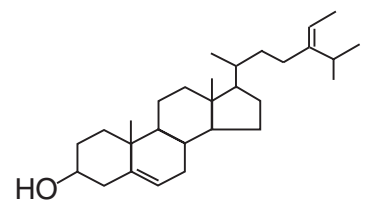

(iv)

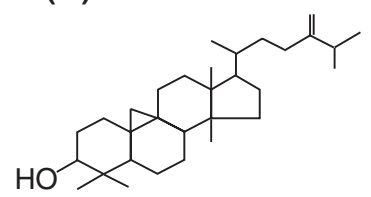

(vi)

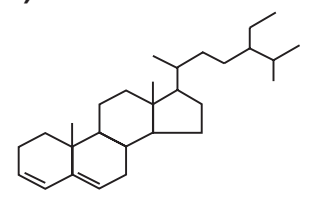

(viii)

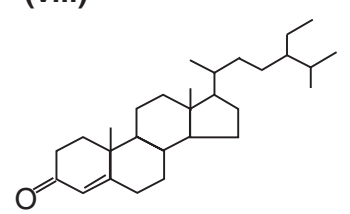

(x)

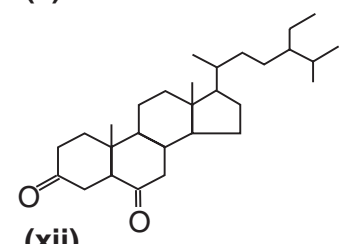

(xii) $\overline{\text { TRENDS in Biotechnology }}$

Fig. II. Main steroid compounds identified in the acetone extracts from Eucalyptus globulus wood and pitch deposits, during manufacturing of chlorine-free eucalypt kraft pulp. Sterols found as free or esterified (i, campesterol; ii, sitosterol; iii, stigmastanol; iv, fucosterol; v, cycloartenol; vi, 24-methylenecycloartanol; vii, citrostadienol); steroid hydrocarbons (viii, stigmasta-3,5-diene) and steroid ketones (ix, stigmasta-3,5-dien-7-one; $\mathbf{x}$, stigmast4-en-3-one; $\mathbf{x i}$, stigmastan-3-one; xii, stigmasta-3,6-dione).

Wood decay fungi are of considerable biotechnological interest in paper pulp manufacturing (Box 3, Ref. 21). The first patent on pitch biocontrol describes the use of conidial fungi from the genera Penicillium, Trichoderma and Gliocladium $^{22}$ but no information on their efficiency in removing extractives is given. Another patent describes wood treatment with sapstain ascomycetes from the genera Ophiostoma and Ceratocystis and their conidial states, as well as other ascomycete-type fungi and was filed in 1990 (Ref. 23). Simultaneously with removal of extractives, a decrease in pulp brightness was observed because of the production of dark pigments by wild sapstain fungi. To overcome this problem, non-pigmented strains of $O$. piliferum were obtained using classical genetics techniques. The use of these colorless fungi for biological control of pitch were covered by several patents ${ }^{24-26}$, and marketed by Clariant Corporation under the trade name Cartapip ${ }^{\circledR}$. In mill-scale trials, in both the US and Finland, a $40 \%$ reduction of pine extractives was obtained after a two-week treatment of wood chips compared with only $20 \%$ removal after natural seasoning $^{27-29}$. Table 2 gives a list of some woods on which Cartapip ${ }^{\circledR}$ has been assessed for its ability to remove total extractive. Wood treatment with this commercial fungus also results in the biocontrol of other organisms, including wild sapstain fungi.

For pitch control, it is important to analyze the removal not only of the total extractives but also of the individual lipid classes. For example, Cartapip ${ }^{\circledR}$ treatment removes up to $50 \%$ of eucalypt extractives (Table 2) but this does not decrease pitch during kraft pulping because the lipophilic compounds responsible for deposits (a minor fraction in eucalypt extractives) are not degraded efficiently. Triglycerides are the most problematic compounds during the manufacturing of mechanical and acidic sulfite pulps from pine and other softwoods. A 90\% decrease of these compounds can be obtained with Cartapip ${ }^{\circledR}$ treatment of pine wood, a percentage significantly higher than that obtained after seasoning ${ }^{29}$. However, the decrease in content of resin acids, sterol ester and waxes after a two-week treatment of this wood with Cartapip ${ }^{\circledR}$ is often similar to that obtained after natural seasoning under the same conditions ${ }^{29,30}$. Despite this limitation, Cartapip ${ }^{\circledR}$ fills a specific niche and provides efficient control for pitch deposits in mechanical and acidic sulfite pulping. This product opened the field of microbial control of pitch and new products must be developed to tackle other pitch problems. Indeed, a recent screening has shown some sapstain fungi with better performances than Cartapip ${ }^{\circledR}$ for softwood depitching ${ }^{31,32}$.

\section{Pitch biocontrol with selected basidiomycetes}

Triglycerides and fatty acids are degraded by a variety of fungi, but resin acids, free and esterified sterols and waxes are more recalcitrant towards microbial degradation ${ }^{33-35}$. As previously described, several sapstain fungi remove some of the main constituents of softwood extractives, however, the best results in terms of resin acid degradation have been obtained with some of the white-rot basidiomycetes (Box 3, Refs 35,36). These fungi simultaneously decreased the potential toxicity of mechanical pulping effluents. Similar results were obtained in a recent study on the biodegradation of steroids responsible for pitch deposits in eucalypt pulp manufacturing. A large number of fungal 


\section{Box 3. Wood-rotting fungi: their biotechnological potential}

The ability to colonize lignified plant material is a characteristic of wood decay fungi, which include white-rot, brown-rot, soft-rot and sapstain species. The fungi that cause white-rot and brown-rot are basidiomycetes and are characterized by their ability to degrade lignin and cellulose respectively, resulting in white (cellulose enriched) or brown-colored (lignin enriched) decayed substrates. The soft-rot fungi are ascomycetes, or ascomycete-type conidial fungi and produce cavities in the secondary cell wall after a limited degradation of carbohydrates. The typical sapstain fungi, also called 'blue-staining fungi', colonize wood vessels and rays (as well as softwood resin canals) penetrating through the cell-wall pits. Penetrating fungi is a broader term for sapstain species, which also includes some related wood colonizing fungi. The growth of sapstain fungi is supported by easily degradable extractives and/or water-soluble constituents and causes discoloration and minimal weight loss. Wood discoloration is caused by the presence of dark pigments (melanins) that have a role in the protection of fungal hyphae against radiation. Because most lipophilic compounds involved in the formation of pitch deposits are concentrated in wood rays and resin canals, the sapstain fungi were the first candidates for the biological control of pitch during wood pulping. Wood-rotting basidiomycetes have also been investigated for biotechnological application in paper pulp manufacturing. 'Brown-rotters' are of little applied interest because they degrade cellulose, the most valuable wood constituent for industrial utilization. However, some white-rot fungi produce a selective degradation pattern characterized by the preferential removal of lignin, the cementing agent between cellulosic fibers. The material obtained is similar to paper pulp obtained by alkaline cooking. Biopulping, in combination with chemical and/or mechanical treatments, represents an attractive alternative to reduce the consumption of pulping chemicals and/or energy. White-rot fungi and their enzymes are also of biotechnological interest for pulp bleaching. The main purpose of biobleaching is to reduce the consumption of the chlorinated reagents traditionally used to bleach pulp, which have a detrimental impact in the water environment. The possibility of combining the advantages associated with the use of white-rot fungi treatments in paper-pulp manufacturing, such as the removal of lignin or lignin-derived compounds, and the degradation of lipophilic extractives is also being considered.

species (21 ascomycetes, 33 basidiomycetes and 19 conidial fungi) including strains isolated from eucalypt wood, were screened ${ }^{37}$. The different patterns of lipophilic compound biodegradation were analyzed ${ }^{38}$ and the time-course of the fungal removal of these compounds was followed to optimize the time duration of the treatment ${ }^{34}$. Several ascomycete-type fungi including Cartapip ${ }^{\circledR}$ were proved ineffective for pitch control in eucalypt

Table 2. Total extractives $\left(\mathbf{g}^{100} \mathrm{~g}^{-1}\right)$ after two-week seasoning and Cartapip ${ }^{\circledR}$ (colorless Ophiostoma piliferum) treatment of different pulpwoods (parentheses, percentage decrease)

\begin{tabular}{|lcllr|}
\hline & Control & Seasoning & Cartapip $^{\circledR}$ & Refs \\
\hline Pinus taeda & 2.6 & $2.0(23 \%)$ & $1.4(46 \%)$ & 27 \\
Pinus virginiana and Pinus taeda & 3.0 & $2.3(23 \%)$ & $1.8(40 \%)$ & 29 \\
Populus tremuloides & 3.1 & $2.9(6 \%)$ & $2.2(29 \%)$ & 30 \\
Pinus contorta & 2.3 & $2.3(0 \%)$ & $1.9(17 \%)$ & 30 \\
Eucalyptus globulus & 1.5 & $1.2(20 \%)$ & $0.8(50 \%)$ & 19,38 \\
\hline
\end{tabular}

pulp because they decreased sterol ester content but did not lower the amount of free sterols. The decrease in the level of sterol esters is related to the esterase activity produced by this fungus ${ }^{39}$. However, several white-rot basidiomycetes were selected because of their ability to efficiently remove both sitosterol and sitosterol esters (Fig. 1) responsible for pitch deposits in TCF bleaching (Box 2). These fungi were also able to degrade other steroids that resist chlorine dioxide treatment and are involved in deposit formation during ECF bleaching ${ }^{15}$. Recently, the ability of basidiomycetes to hydrolyze sterol esters and waxes in liquid culture has been reported ${ }^{33}$. As shown in Box 4, kraft cooking and TCF bleaching of the eucalypt chips treated with four selected basidiomycetes, followed by papermaking evaluation of the pulps, confirmed their potential for pitch biocontrol in hardwood pulping ${ }^{40,41}$. The 'biopulps' obtained contain up to 60-70\% less sitosterol and sitosterol esters and maintained their mechanical and optical properties. Wood pretreatments with these basidiomycetes also result in lowering the lignin content. The possibility to combine both extractives and lignin removal in a wood biopulping treatment with white-rot fungi has already been suggested $^{42-44}$. In addition, it has been shown that fungal pretreatment of wood strongly decreases the potential toxicity of effluents owing to the biological removal of some extractive ${ }^{36,40}$. In this way, multipurpose biopulping strategies can be designed, with the following aims: (1) controlling pitch deposition; (2) saving chemicals and/or energy during the pulping and bleaching processes; (3) reducing their environmental impact; and (4) improving the optical and/or mechanical properties of pulps.

\section{Enzymatic removal of lipophilic compounds from paper pulp and process waters}

The use of enzymes in the pulp and paper industry has grown rapidly since the mid 1980s. Although many of these applications are still at the research and development stage, some of them have found their way into the mills in an unprecedented short period of time. One of the best examples is the enzymatic control of pitch in softwood mechanical pulps using lipases (triacylglycerol acylhydrolases, EC 3.1.1.3), which was put into practice in a largescale paper-making process as a routine operation in the early 1990s (Ref. 45). However, it is important to note that the addition of lipases to pulp constitutes a prophylactic measure to prevent deposit formation but it is not effective in the removal of previously formed pitch deposits.

Lipases are a group of hydrolases that have been characterized from a variety of organisms. They are of particular interest in detergent formulation and paper pulp manufacturing as well as in many other industrial applications ${ }^{46-48}$. Lipase treatments of 


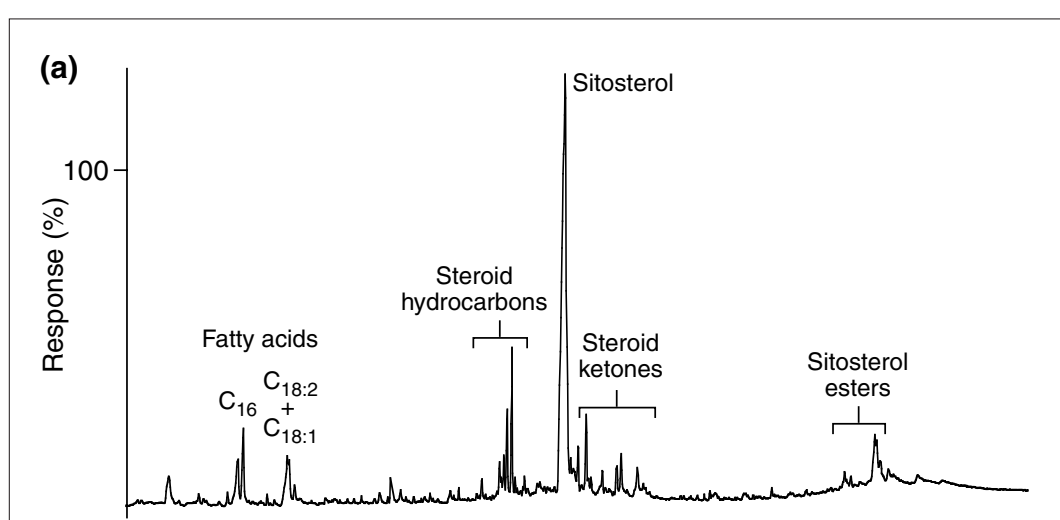

(b)

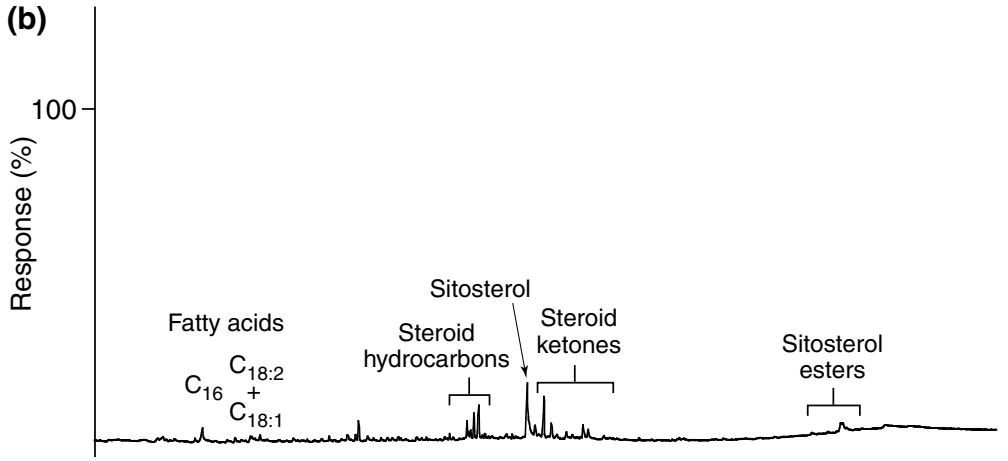

(c)

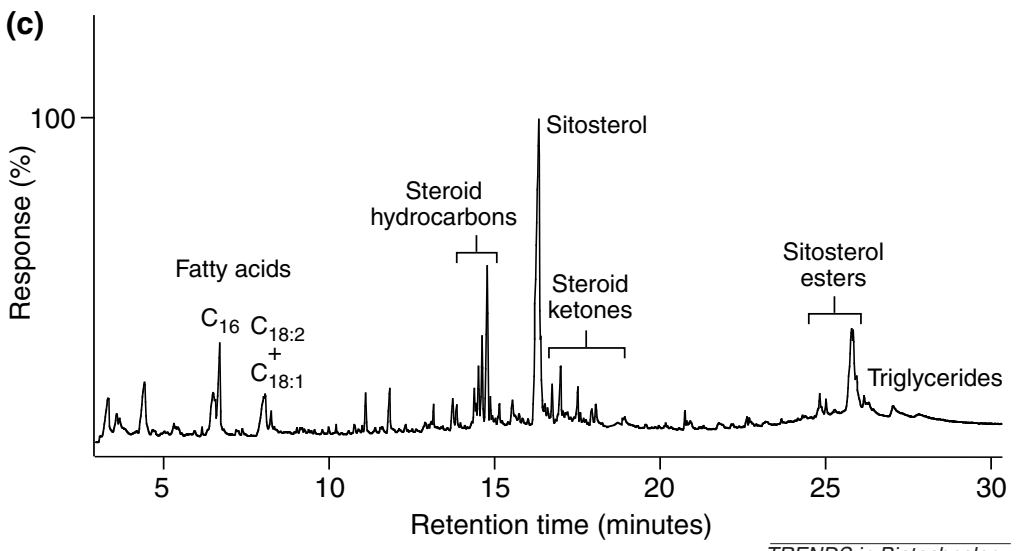

Fig. 1. Gas

chromatography-mass spectrometry (GC-MS) profiles of lipophilic

fraction after eucalypt wood treatment with (a) Cartapip ${ }^{\circledR}$ (white

Ophiostoma piliferum), (b) Phlebia radiata and (c) the corresponding control. Eucalyptus globulus wood was treated with the fungi under solid-state fermentation conditions. After 40 days at $28^{\circ} \mathrm{C}$, the treated wood was dried $\left(60^{\circ} \mathrm{C}\right)$, milled, Soxhletextracted with acetone, and the chloroform soluble fraction analyzed using GC-MS (Ref. 38).
Resinase ${ }^{\circledR}$ have also provided promising results ${ }^{53-55}$. However, lipase treatments have not yet been successfully introduced in the US paper industry, in which the percentage of wood pulped by mechanical processes is lower than in Europe. Fleet and Breuil ${ }^{56}$ have shown that wood impregnation with sodium hydrosulfite before refining - a common practice in mills in North America - does not affect the effectiveness of the lipase treatment. They suggested that fluctuations in the fatty acid concentrations of the pulps might explain the variable success of the lipase treatment because a high ratio between free fatty acids and triglycerides inhibits esterase activity ${ }^{56}$. This drawback could be overcome by the addition of cationic polymers retaining free fatty acids ${ }^{57}$.

In addition to Resinase ${ }^{\circledR}$, other industrial lipases such as Lipidase 10000 (American Lab. Inc.) and Candida and Aspergillus lipases - have been investigated for the enzymatic control of pitch $^{45,52,56,58,59}$. All of these enzymes act on glycerides but do not degrade other extractives that form pitch deposits. Thus, enzymes acting on a broader range of substrates are being investigated, and different groups of organisms are presently undergoing screening for new enzymes ${ }^{60,61}$.

Sterol esterases (steryl-ester acylhydrolases, E.C. 3.1.1.13), a less well-characterized group of hydrolases, could also be of considerable importance for pitch control because sterol esters are often at the origin of deposits, owing to their high tackiness and resistance to kraft cooking. These enzymes are produced by mammalian tissues, several fungi and bacteria, but none of them has reached industrial production ${ }^{60,62-67}$. However, activity on sterol esters has been found in several lipases ${ }^{39,68,69}$. Little is known about the enzymes involved in enzymatic degradation of sterols and resin acids, even though the microbial degradation of these compounds has been reported ${ }^{11,70-72}$. Finally, it has been shown that glucomannans in process waters from mechanical pulping, stabilize pitch particles ${ }^{73}$ and that treatment with mannase results in pitch fixation on fibers ${ }^{74,75}$.

Protein engineering techniques are being used to improve the performances of lipolytic enzymes in different industrial applications, including paper pulp manufacturing, as a complementary approach to the search for new enzymes ${ }^{48}$. Among the different factors to be improved by the above techniques are substrate specificity, and $\mathrm{pH}$ and temperature activity, and stability. Concerning substrate specificity, it has already been mentioned that commercial lipases can be used to control pitch problems caused by glycerol esters but they are ineffective on sterol esters. Therefore, lipase protein engineering enabling these enzymes to hydrolyze esters of sterols constitutes an attractive approach. Moreover, increasing enzymatic activity at high temperatures is important in mechanical pulping 


\section{Box 4. Biokraft pulping of eucalypt wood}

Commercial products such as Albinex ${ }^{\circledR}$ (formerly Cartapip ${ }^{\circledR}$ ) from Agrasol Inc. and Resinase ${ }^{\circledR}$ for the control of triglyceridecontaining pitch deposits in softwood mechanical and acidic sulfite pulps, are on the market. Pitch problems are different during eucalypt kraft pulping because steroids are relatively recalcitrant to biodegradation and are mainly responsible for the deposits (Box 2). A multidisciplinary study on pitch biocontrol during manufacturing of eucalypt kraft pulps was initiated in 1996. Four strains from the white-rot basidiomycetes Bjerkandera adusta, Phlebia radiata, Pleurotus pulmonarius and Poria subvermispora were selected for eucalypt wood pretreatment in a rotary fermenter under solid-state fermentation conditions. After three weeks, kraft cooking of the fungally-treated wood and TCF bleaching, including oxygen delignification and hydrogen peroxide treatment, were carried out in the laboratory. Changes in the composition of the lipophilic fractions of wood, pulp and black liquor as a consequence of the biological pretreatment of wood were analyzed by gas chromatography-mass spectrometry (GC-MS). Changes of lignin content in wood and pulps after fungal treatment were analyzed as Klason lignin and kappa numbers following Tappi rules. To evaluate the potential of the fungal pretreatment of wood in paper pulp manufacturing, different pulping and papermaking parameters (including yield, viscosity, brightness, fiber length, beating degree, density, tensile index, tear index, burst index, air permeability, scattering coefficient and opacity) were evaluated
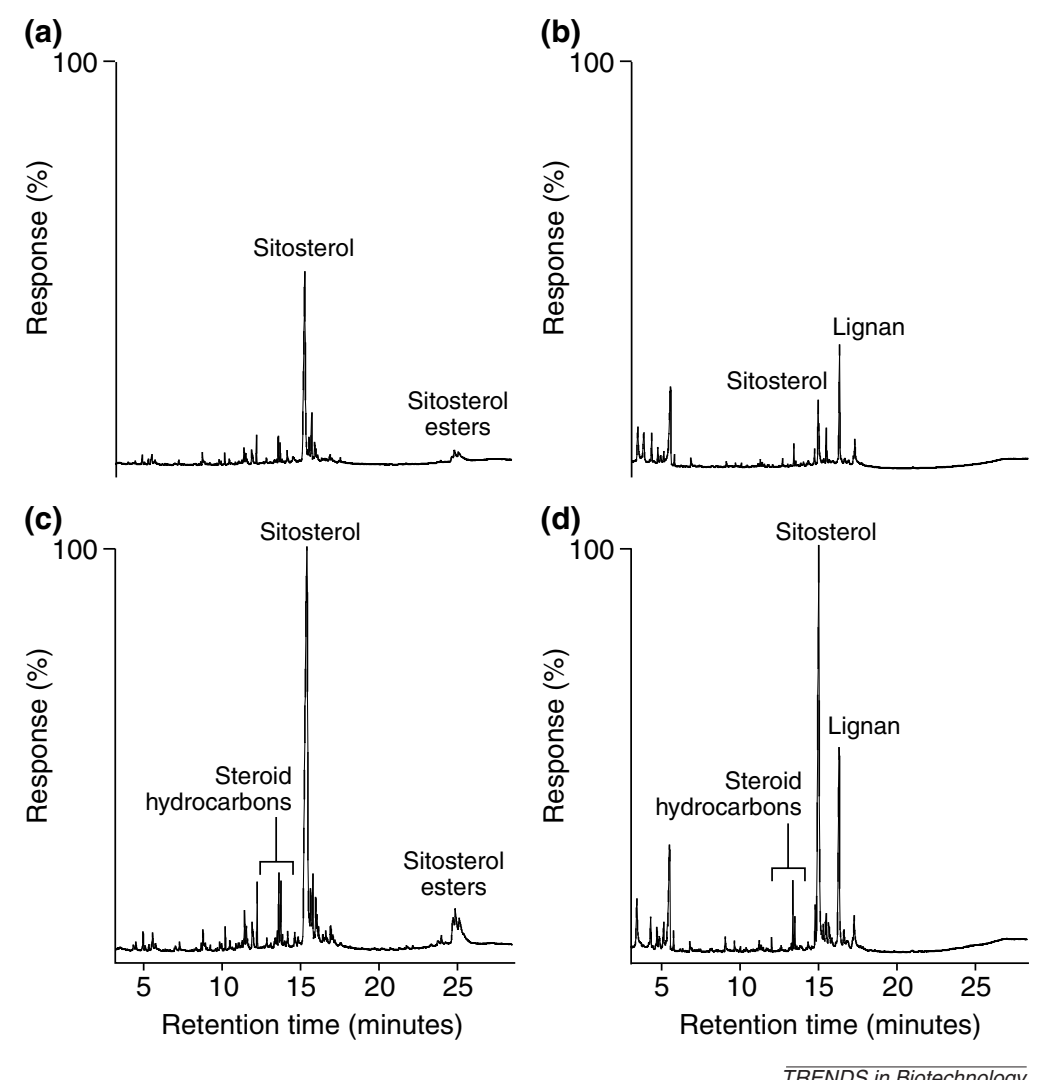

Fig. I. Gas chromatography-mass spectrometry (GC-MS) profiles of lipophilic compounds in eucalypt kraft pulp (left) and black liquor (right) from wood treated with Phlebia radiata ( $a$ and b) and the corresponding controls (c and d) ${ }^{40}$.

using ISO standard procedures. In this way, it was shown that the degradation of steroids during eucalypt wood pretreatment resulted in lower amounts of these compounds in both pulps and cooking black liquors (Fig. I). Moreover, the papermaking properties of the biokraft pulps obtained were similar to those of control pulps. A decrease of air porosity and improvement of some mechanical properties was observed. The yield decrease was moderate in most cases. Pilot-scale trials should be carried out to optimize treatment conditions and duration, to attain the highest reduction of lignin content in wood, and free and esterified sterols in pulps and liquors, with the lowest reduction of pulp yield. because, for optimal performance, the lipase should be added to the pulp at a temperature of $\sim 80^{\circ} \mathrm{C}$. In a similar way, enzymes acting at high $\mathrm{pH}$ and temperature would be desirable for pitch biocontrol in some chemical pulping processes.

The first molecular structure of a lipase was reported ten years ago for the enzyme isolated from Rhizomucor miehei and the architecture of its active center described ${ }^{76}$. The lipid contact zone includes a 'flap' that is opened when in contact with the substrate, exposing the catalytic region. Currently, the crystal structures of at least 12 lipases from fungi and bacteria have been reported in addition to mammal lipases (see Protein Data Bank http://www.rcsb.org/pdb/index.html). By contrast, only the crystal structures of bovine ${ }^{77}$ and C. cylindracea ${ }^{78}$ sterol esterases (Fig. 2) are currently available. Although highly homologous with Candida rugosa lipase (89\% identity; Ref. 79), the location and nature of the sequence differences in $C$. cylindracea sterol esterase are consistent with altered substrate specificity - many of them being located in the active site and surrounding regions. With substrate specificity altered from glycerol to sterol esters, it is not surprising that the sterol esterase has a more hydrophobic substrate binding pocket. Taking this information into account, it should be possible to modify (using site-directed mutagenesis) different residues of the active site of lipases to obtain variants with higher activity or modified substrate specificity 
Fig. 2. Schematic model for fungal sterol esterase complex with cholesteryl linoleate (PDB entry 1CLE; Ref. 78). The $\alpha$ helices are shown in red and the $\beta$ sheets in yellow. The cholesteryl linoleate is shown in green.

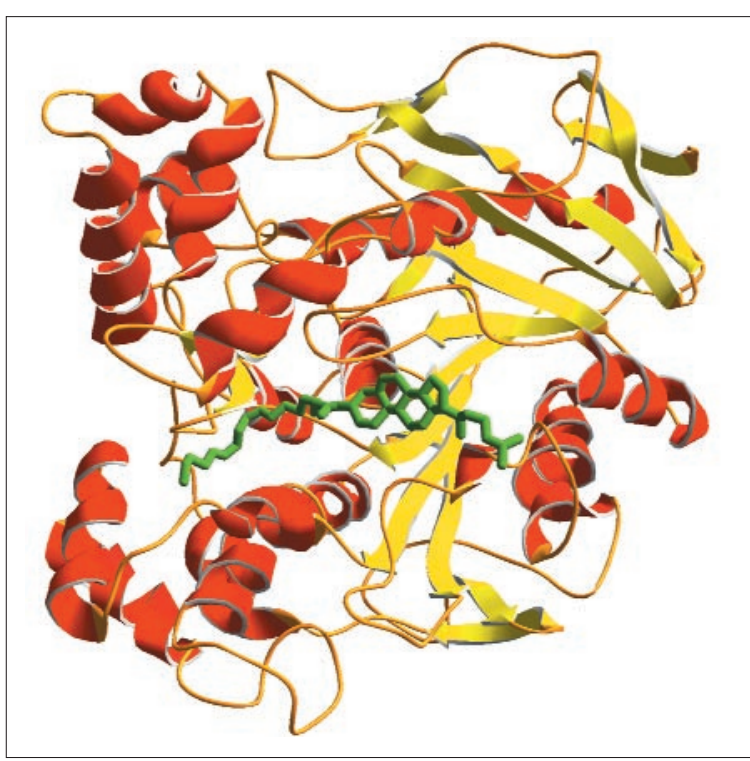

as reported for other industrial applications ${ }^{48}$. Given that the structural bases for lipase resistance to high temperature or extreme $\mathrm{pH}$ are not well understood, random mutagenesis strategies should be combined with site-directed mutagenesis to produce lipases with improved properties for their application in the mill. In this way, new generations of tailor-made lipolytic enzymes, better adapted to the high variability of pitch problems in the different paper pulp manufacturing processes, could be available in the near future.

\section{Conclusions}

To determine the potential of a particular biological treatment, the heterogeneity of wood extractives and their behavior under different pulping and bleaching conditions must be understood. After determining which classes of lipids are important in each pitch problem, it will be possible to assess the effectiveness of the biological agents in removing the troublesome lipids, without lowering the quality of the final product. Microbial preparations currently on the market (based on colorless strains of the sapstain ascomycete $O$. piliferum) efficiently contribute to pitch control in pine and other softwood mechanical pulping processes, as well as in acidic sulfite pulping, in which it is the triglycerides that are responsible for the majority of the deposits. In other pulping processes (e.g. using wood with high content of other lipophilic extractives or cooking conditions saponifying triglycerides) steroids are among the most problematic compounds. Fungal strains that strongly degrade free and esterified sterols from eucalypt wood have been selected and their performance evaluated in kraft cooking and TCF bleaching under laboratory conditions. In addition, fungal treatments often result in a reduction in the potential toxicity of mill effluents, especially in the pulping of softwoods containing highly toxic resin acids. Future microbial preparations for use in paper pulp manufacturing could combine the efficient removal of recalcitrant lipophilic extractives and a decrease in effluent toxicity, and being capable of being adapted to different pulp manufacturing processes.

Enzyme preparations (added to pulp or process waters) offer considerable advantages when compared with fungal inocula (applied to the wood before pulping) owing to shorter treatment times and greater specificity in the removal of wood components. However, some compounds that can be efficiently degraded by fungi are not removed by the enzymes currently available. Commercial lipases are only useful for pitch control in softwood mechanical pulping (promising results have also been obtained in acidic sulfite pulping). They can hydrolyze most pulp triglycerides following a few hours of treatment but do not decrease the amount of sterol esters and in fact increase the amount of free fatty acids. The enzymatic control of pitch deposits in different hardwood pulps (as well as in some softwood pulps) would require the use of enzymes able to hydrolyze sterol esters. However, only a small number of these enzymes have been characterized and none are produced for industrial applications. Alternatively, substrate specificity of commercial lipases could be manipulated using molecular biology techniques and simultaneously, the temperature and $\mathrm{pH}$ resistance of these enzymes could be tailored to better fit true mill conditions.

QLK5-99-1357 and the

Spanish project 1FD97-742.

\section{References}

1 Hillis, W.E. (1962) Wood Extractive, Academic Press

2 Fengel, D. and Wegener, G. (1984) Wood: Chemistry, Ultrastructure, Reactions, De Gruyter

3 Rowe, J.W. (1989) Natural Products of Woody Plants. I and II. Chemicals Extraneous to the Lignocellulosic Cell Wall, Springer-Verlag

4 Gutiérrez, A. et al. (1999) Chemical composition of lipophilic extractives from Eucalyptus globulus Labill. wood. Holzforschung 53, 481-486

5 Back, E.L. (2000) The location and morphology of resin components in the wood. In Pitch control, wood resin and deresination (Back, E.L. and Allen, L.H., eds), pp. 1-35, TAPPI press 6 Sjöström, E. (1993) Wood Chemistry. Fundamentals and Applications, Academic Press
7 Hillis, W.E. and Sumimoto, M. (1989) Effect of extractive on pulping. In Natural Products of Woody Plants II (Rowe, J.W., ed.), pp. 880-920, Springer-Verlag

8 Allen, L.H. (2000) Pitch control in pulp mills. In Pitch Control, Wood Resin and Deresination (Back, E.L. andAllen, L.H., eds), pp. 265-288, TAPPI Press

9 Allen, L.H. (2000) Pitch control in paper mills. In Pitch Control, Wood Resin and Deresination (Back, E.L. and Allen, L.H., eds), pp. 307-328, TAPPI Press

10 Leach, J.M. and Thakore, A.N. (1976) Toxic constituents in mechanical pulping effluents. Tappi J. 59, 129-132

11 Liss, S.N. et al. (1997) Microbiology and biodegradation of resin acids in pulp mill effluents: a minireview. Can. J. Microbiol. 43, 599-611

12 Brush, T.et al. (1994) Biodegradation of wood extractive from Southern and Yellow pine by Ophiostoma piliferum. Tappi J. 77, 155-159

13 Holmbom, B. (2000) Resin reactions and deresination in bleaching. In Pitch Control, Wood Resin and Deresination (Back, E.L. and Allen, L.H., eds), pp. 231-244, Tappi Press

14 del Río, J.C. et al. (2000) Analysis of pitch deposits produced in Kraft pulp mills using a totally chlorine free bleaching sequence. J. Chromatogr. A 874, 235-245

15 del Río, J.C. et al. (1998) Characterization of organic deposits produced in the Kraft pulping of Eucalyptus globulus wood. J. Chromatogr. 823, 457-465 
16 del Río, J.C. et al. (1999) Analysis of impurities occurring in a totally-chlorine free-bleached Kraft pulp. J. Chromatogr. 830, 227-232

17 Chen, T. et al. (1995) Using solid-phase extraction to assess why aspen causes more pitch problems than softwoods in kraft pulping.

Tappi J. 78, 143-149

18 Ekman, R. (2000) Resin during storage and its biological treatment. In Pitch Control, Wood Resin and Deresination (Back, E.L. and Allen, L.H. eds), pp. 185-204, Tappi Press

19 Gutiérrez, A. et al. (1998) Variation in the composition of wood extractive from Eucalyptus globulus during seasoning. J. Wood Chem. Technol. 18, 439-446

20 Breuil, C.et al. (1998) Fungal treatment of wood chips to remove extractive. In Environmentally Friendly Technologies for the Pulp and Paper Industry (Young, R.A. and Akhtar, M., eds), pp. 541-566, TAPPI Press

21 Zabel, R. and Morrell, J. (1992) Wood Microbiology: Decay and its Prevention, Academic Press

22 Nilsson, T. and Asserson, A. (1966) Patent (USA) No. 3486 ,

23 Blanchette, R.A. et al. (1990) Process for reducing the pitch content in pulpwood. Patent (European) No. EP0387187

24 Farrell, R.L.et al. (1992) New fungi for pitch reduction, their preparation and use. Patent (European) No. EP0470929

25 Farrell, R.L. et al. (1995) Composition containing strains of Ophiostoma piliferum and a method of using the composition to reduce the pitch content of pulpwood or pulp. Patent (USA) No. 5,476,789

26 Blanchette, R.A. et al. (1998) Process for treating pulpwoods and pulps with a pitch degrading fungus of the genus Ophiostoma. Patent (USA) No. 5,853,537

27 Blanchette, R.A. et al. (1992) Biological control of pitch in pulp and paper production by Ophiostoma piliferum. Tappi J. 75, 102-106

28 Perrolaz, J.J. (1992) Biological pretreatment of chips: a new technology to improve the quality of mechanical pulps. Rev. ATIP 46(1), 12-16

29 Farrell, R.L.et al. (1993) Cartapip ${ }^{\mathrm{TM}}$ : a biopulping product for control of pitch and resin acid problems in pulp mills. J. Biotechnol. 30, 115-122

30 Chen, T.et al. (1994) Wood extractive and pitch problems: analysis and partial removal by biological treatment. Appita 47, 463-466

31 Dorado, J. et al. (2000) Degradation and detoxification of softwood extractive by sapstain fungi. Bioresource Technol. 71, 13-20

32 Martínez-Íñigo, M.J. et al. (2000) Evaluation of fungal capacity for detoxification of extractive in Scots pine sapwood. Environ. Technol. 21, 569-575

33 Leone, R. and Breuil, C. (1998) Filamentous fungi can degrade aspen steryl esters and waxes. Int. Biodeterior. Biodegrad. 41, 133-137

34 Martínez-Íñigo, M.J. et al. (2000) Time course of fungal removal of lipophilic extractive from Eucalyptus globulus Labill. wood. J. Biotechnol. 84, 119-126

35 Martínez-Íñigo, M.J.et al. (1999) Biodegradability of extractive in sapwood and heartwood from Scots pine by sapstain and white-rot fungi. Holzforschung 53, 247-252

36 Dorado, J.et al. (2000) Elimination and detoxification of softwood extractive by white-rot fungi. J. Biotechnol. 80, 231-240
37 Martínez, M.J.et al. (1999) Fungal screening for biological removal of extractive from Eucalyptus globulus Labill. wood. Can. J. Bot. 77, 1513-1522

38 Gutiérrez, A. et al. (1999) Fungal degradation of lipophilic extractive in Eucalyptus globulus wood. Appl. Environ. Microbiol. 65, 1367-1371

39 Brush, T.S. et al. (1999) Purification and characterization of extracellular lipases from Ophiostoma piliferum. Bioorgan. Med. Chem. 7,2131-2138

40 Gutiérrez, A. et al. (2000) Fungal pretreatment of Eucalyptus wood can strongly decrease the amount of lipophilic extractive during chlorine-free kraft pulping. Environ. Sci. Technol. 34, 3705-3709

41 Martínez, M.J.et al. (2000) Procedimiento de eliminación microbiana de compuestos lipofílicos en la fabricación de pasta de papel a partir de madera de frondosas. Patent (Spain) No. solicitud 200000018 (5-Ene-00)

42 Behrendt, C.J. and Blanchette, R.A. (1997) Biological processing of pine logs for pulp and paper production with Phlebiopsis gigantea. Appl. Environ. Microbiol. 63, 1995-2000

43 Blanchette, R.A. et al. (1998) Pitch and lignin degradation with white-rot fungi. Patent (USA) No. US 5,705,383

44 Messner, K. (1998) Biopulping. In Forest Products Biotechnology (Bruce, A. and Palfreyman, J.W., eds), pp. 63-82, Taylor \& Francis

45 Hata, K. et al. (1996) Mill-scale application of enzymatic pitch control during paper production. In Enzymes for Pulp and Paper Processing (Viikari, L. and Jeffries, T.W., eds), pp. 280-296, ACS

46 Björkling, F. et al. (1991) The future impact of industrial lipases. Trends Biotechnol. 9, 360-363

47 Seitz, L.M. (1974) Industrial application of microbial lipases: a review. J. Am. Chem. Soc $51,12-16$

48 Svendsen, A. et al. (1997) Protein engineering of microbial lipases of industrial interest. Methods Enzymol. 284, 317-340

49 Irie, Y. (1990) Enzymatic pitch control in papermaking system. Abs. 1990 Papermakers Confer., 23-25 April, Atlanta

50 Matsukura, M. et al. (1990) On the use of Resinase $^{\mathrm{TM}}$ a for pitch control. Novo Publication A-6122, 1-7

51 Fujita, Y. et al. (1991) Enzymic pitch control in papermaking process. Kami Pa Gikyoshi 45, 905-921

52 Fujita, Y. et al. (1992) Recent advances in enzymic pitch control. Tappi J. 75, 117-122

53 Fischer, K. et al. (1993) Enzymatic pitch control of sulfite pulp on pilot scale. J. Biotechnol. 27, 341-348

54 Fischer, K. and Messner, K. (1992) Biological pitch reduction of sulfite pulp on pilot scale. In Biotechnology in the Pulp and Paper Industry (Kuwahara, M., Shimada, M., eds), pp. 169-174, UNI Publishers

55 Fischer, K. and Messner, K. (1992) Adsorption of lipase on pulp fibers during biological pitch control in paper industry. Enzyme Microb. Technol. 14, 470-473

56 Fleet, C. and Breuil, C. (1998) High concentrations of fatty acids affect the lipase treatment of softwood thermomechanical pulps. Appl. Microbiol. Biotechnol. 49, 517-522

57 Sarkar, J.M. and Finck, M.R. (1993) Method for controlling pitch deposits using lipase and cationic polymer. Patent (USA) No. 5,256,252
58 Qin, M.H. and Chen, J-X. (1997) Biological pitch control of masson pine groundwood pulp by lipases. Proc. TAPPI Biol. Sci. Symp., San Francisco, 19-23 October, 369

59 Mustranta, A. et al. (1995) Effects of lipases on birch extractive. Tappi J. 78, 140-144

60 Okawa, Y. and Yamaguchi, T. (1977) Studies on sterol-ester hydrolase from Fusarium oxysporum. I. Partial purification and properties. J. Biochem. (Tokyo) 81, 1209-1215

61 Martínez-Íñigo, M.J.et al. (1997) Screening of lipase-producing fungal strains useful for pitch control. Abs. Intern. Symp. Environ. Biotechnol. 21-24 April, Oostende

62 Gandarias, J.M. et al. (1987) Kinetic properties and solubilization of microsomal cholesterol ester hydrolase from rat liver. Steroids 49, 403-417

63 Rahim, M.A. and Sih, C.J. (1969) Microbial steroid esterases. Methods Enzymol. 15, 675-684

64 Sih, C.J.et al. (1963) Purification and properties of steroid sterase from Nocardia restrictus. J. Biol. Chem. 238, 566-571

65 Kaiser, R. et al. (1994) Monomeric and dimeric forms of cholesterol esterase from Candida cylindracea. FEBS Lett. 337, 123-127

66 Madhosingh, C. and Orr, W. (1981) Sterol ester hydrolase in Fusarium oxysporum.

Lipids 16, 125-132

67 Taketani, S. et al. (1981) Purification and properties of sterol-ester hydrolase from Saccharomyces cerevisiae. J. Biochem. (Tokyo) 89, 1667-1673

68 Gao, Y. and Breuil, C. (1998) Properties and substrate specificities of an extracellular lipase purified from Ophiostoma piceae. World J. Microbiol. Biotechnol. 14, 421-429

69 Svendsen, A. et al. (1995) Biochemical properties of cloned lipases from the Pseudomonas family. Biochim. Biophys. Acta 1258, 9-17

70 Satyanarayana, T. and Chavant, L. (1987) Bioconversion and binding of sterols by thermophilic moulds. Folia Microbiol. (Prague) 32, 354-359

71 Marsheck, W.J.et al. (1972) Microbial degradation of sterols. Appl. Microbiol. 23, 72-77

72 Hata, K. et al. (1998) Biodegradation of resin acids in pulp and paper industry: Application of microorganisms and their enzymes.

ACS Symp. Ser. 687, 27-40

73 Back, E.L. (2000) Resin in suspensions and mechanisms of its deposition. In Pitch Control, Wood Resin and Deresination (Back, E.L., Allen, L.H., eds), pp. 151-183, TAPPI Press

74 Buchert, J.et al. (1999) Enzymatic control of pitch during mechanical pulping. Proc. 27th EUCEPA Conference Grenoble, 12-14 October, pp. 191-194

75 Kantelinen, A. et al. (1995) Effects on enzymes on the stability of colloidal pitch. Proc. 8th Intern. Symp. Wood and Pulping Chem. 605-612

76 Brady, L. et al. (1990) A serine protease triad forms the catalytic centre of a triacylglycerol lipase. Nature 343, 767-770

77 Wang, X. and Zhang, X. (1997) The crystal structure of bovine bile salt activated lipase: Insights into the bile salt activation mechanism. Structure 5, 1209-1218

78 Ghosh, D. et al. (1995) Structure of uncomplexed and linoleate-bound Candida cylindracea cholesterol esterase. Structure 3, 279-288

79 Grochulski, P.et al. (1993) Insights into interfacial activation from an open structure of Candida rugosa lipase. J. Biol. Chem. 268, 12843-12847 